\title{
Clinical Experiences with a Modified BFM Protocol in Childhood Acute Lymphoblastic Leukemia *
}

\author{
F. Zintl, H. Malke, and W. Plenert
}

\section{A. Introduction}

The most important problem in current therapy of childhood acute lymphoblastic leukemia (ALL) is a failure in over one-half of patients. We were unable to increase the failure-free survival of children with high risk ALL by a ten-drug regimen (modified $\mathrm{LSA}_{2} \mathrm{~L}_{2}$ ) above $30 \%$ at 6 years [1].

The results of the West Berlin therapy study between 1970 and 1976 confirmed

* Universitäts-Kinderklinik Jena, Abt. Hämatologie/Onkologie/Immunologie, Kochstraße 2, 6900 Jena, GDR the hypothesis that intensification and prolongation of remission induction produce a higher percentage of disease-free long-term survivors [2]. We decided in 1981 to adopt a modified BFM protocol for ALL therapy in our group [3]. This paper presents preliminary results of this multicenter randomized study.

\section{B. Materials and Methods}

I. Patients

A total of 208 consecutive, previously untreated children with ALL were entered in-

Table 1. Characteristics of patients in the study

\begin{tabular}{|c|c|c|c|c|c|c|c|c|}
\hline \multirow[t]{2}{*}{ Characteristics } & \multicolumn{2}{|c|}{ Total } & \multicolumn{2}{|l|}{ SR } & \multicolumn{2}{|c|}{ MR } & \multicolumn{2}{|c|}{ HR } \\
\hline & $N$ & $(\%)$ & $N$ & $(\%)$ & $N$ & $(\%)$ & $N$ & $(\%)$ \\
\hline \multirow{4}{*}{$\begin{array}{l}\text { Patients } \\
\text { Median age at diagnosis (years) } \\
2 \text { years } \\
10 \text { years }\end{array}$} & 208 & 100 & 133 & 100 & 60 & 100 & 15 & 100 \\
\hline & 5 & $3 / 12$ & 5 & $1 / 12$ & 5 & $3 / 12$ & 9 & $10 / 12$ \\
\hline & 13 & 6 & 5 & 4 & 5 & 8 & 3 & 20 \\
\hline & 49 & 24 & 31 & 23 & 12 & 20 & 6 & 40 \\
\hline \multirow{2}{*}{$\begin{array}{l}\text { Boys } \\
\text { Median age at diagnosis (years) }\end{array}$} & 111 & 53 & 79 & 59 & 23 & 38 & 9 & 60 \\
\hline & 5 & $10 / 12$ & 5 & $5 / 12$ & 5 & $4 / 12$ & 11 & $0 / 12$ \\
\hline \multirow{2}{*}{$\begin{array}{l}\text { Girls } \\
\text { Medianage at diagnosis (years) }\end{array}$} & 97 & 47 & 54 & 41 & 37 & 62 & 6 & 40 \\
\hline & 4 & $9 / 12$ & 4 & $10 / 12$ & 5 & $2 / 12$ & 3 & $10 / 12$ \\
\hline \multirow{3}{*}{$\begin{array}{lr}\text { Leukocytes } \begin{array}{r}25000 / \mathrm{mm}^{3} \\
50000 / \mathrm{mm}^{3} \\
100000 / \mathrm{mm}^{3}\end{array}\end{array}$} & 55 & 26 & 11 & 8 & 34 & 57 & 10 & 67 \\
\hline & 32 & 15 & 2 & 2 & 20 & 33 & 10 & 67 \\
\hline & 16 & 8 & & 0 & 7 & 12 & 9 & 60 \\
\hline \multirow{2}{*}{$\begin{array}{l}\text { CNS involvement } \\
\text { Mediastinal mass }\end{array}$} & 9 & 4 & 5 & 4 & 2 & 3 & 2 & 14 \\
\hline & 17 & 8 & 10 & 7 & 2 & 3 & 5 & 33 \\
\hline Liver $5 \mathrm{~cm}$ & 67 & 32 & 15 & 11 & 37 & 62 & 15 & 100 \\
\hline Spleen $5 \mathrm{~cm}$ & 57 & 27 & 9 & 7 & 33 & 55 & 15 & 100 \\
\hline Acid phosphatase positive & 46 & 22 & 26 & 20 & 15 & 25 & 5 & 33 \\
\hline
\end{tabular}


SR

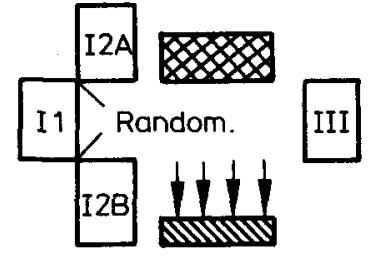

III

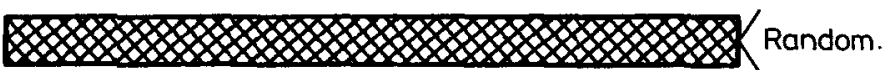

Medium risk patients (RF $1,2<1,7$ )

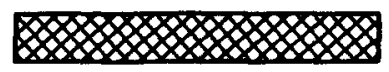

III

MR

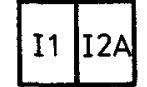

\section{II}

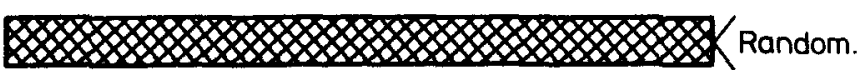

High risk patients (RF $>1,7$ )

HR
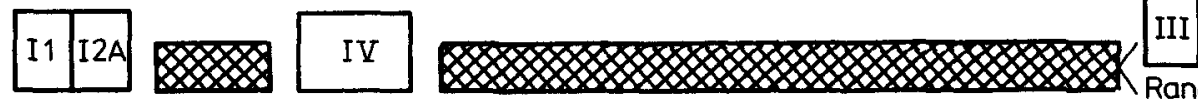

Random.

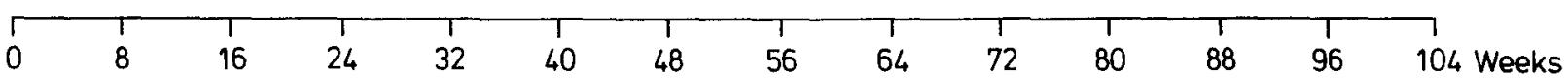

I1: Protocol I Phase 1 (Day 1-28)

I2A/B: Protocol I Phase 2 (Day 29-56)

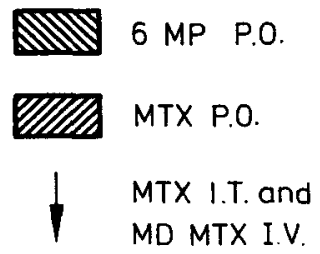

I : Protocol II

III : Protocol III

IV: Protocol IV

spleen enlargement: standard (SR), medium (MR), and high risk (HR) groups [4].

Fig. 1. Schedule for the modified BFM-protocol (ALL study VII/81)

to the study (VII/81) between September 1981 and March 1984. Patients' characteristics are given in Table 1. Patients were divided into three risk groups according to the initial leukocyte count and liver and

Fig. 2. Outline for the induction protocol

\section{Treatment}

The treatment comprises induction therapy with CNS prophylaxis, reinduction therapy, and continuous maintenance therapy (Figs. 1-5). The induction protocol I, con-

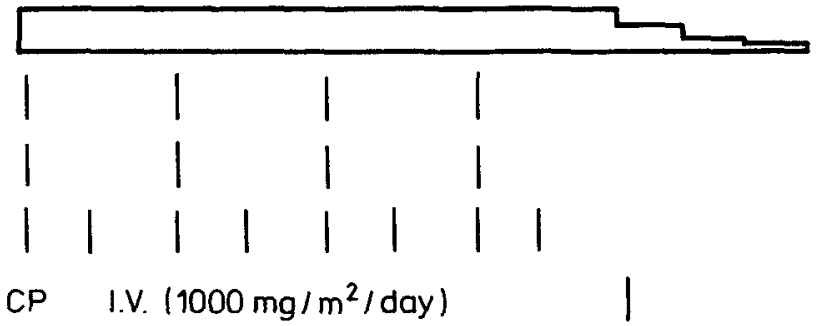

PRED P.O. $\left(60 \mathrm{mg} / \mathrm{m}^{2} /\right.$ day $)$

VCR I.V. $\quad\left(1,5 \mathrm{mg} / \mathrm{m}^{2} /\right.$ day $)$

DAUNO I.V. $\quad\left(30 \mathrm{mg} / \mathrm{m}^{2} /\right.$ day)

L-ASP I.V. $\left(10000 \mathrm{E} / \mathrm{m}^{2} /\right.$ day $)$

CP I.V. $\left(1000 \mathrm{mg} / \mathrm{m}^{2} /\right.$ day $)$

ARA-CI.V. $\left(75 \mathrm{mg} / \mathrm{m}^{2} /\right.$ day)

MTX I.V.

6-MP P.O. $\left(60 \mathrm{mg} / \mathrm{m}^{2} /\right.$ day)

CNS-Irradiation
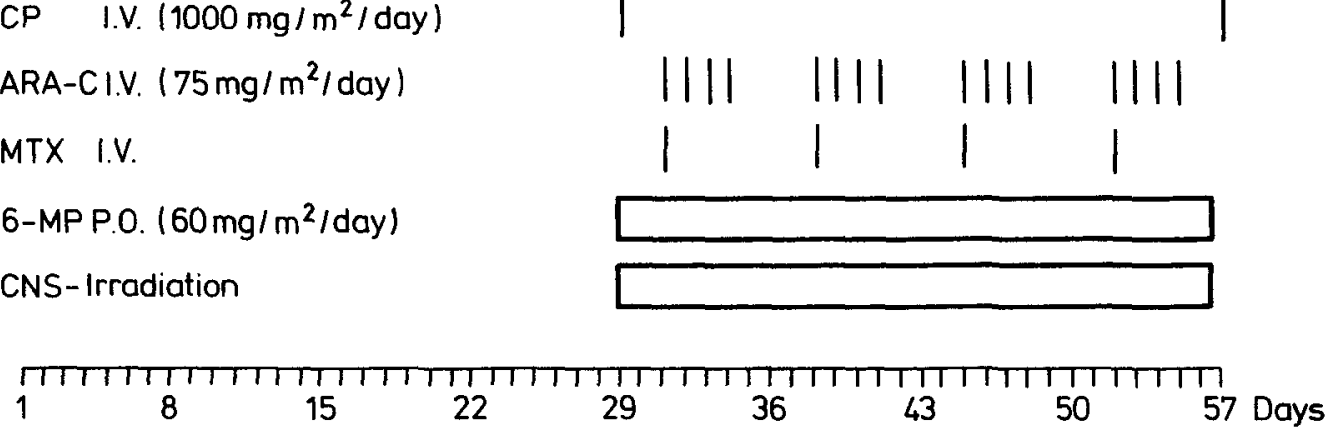

$\begin{array}{rlrrr}\text { MTX-dose: } & <1 \text { year } 6 \mathrm{mg} & \text { CNS-treatment } & \text { Dosage CNS-Irradiation: } \\ >=1 \text { and } & <2 \text { years } 8 \mathrm{mg} \text { randomized in } & & <1 \geqslant 1-<2 \geqslant 2 \text { years } \\ >=2 \text { and } & <3 \text { years } 10 \mathrm{mg} \text { the SR-Group } & \text { SRA/MR } 12 \mathrm{~Gy} 15 \mathrm{~Gy} 18 \mathrm{~Gy} \\ > & =3 \text { years } 12 \mathrm{mg} & & \text { HR } 16 \mathrm{~Gy} 20 \mathrm{~Gy} 24 \mathrm{~Gy}\end{array}$




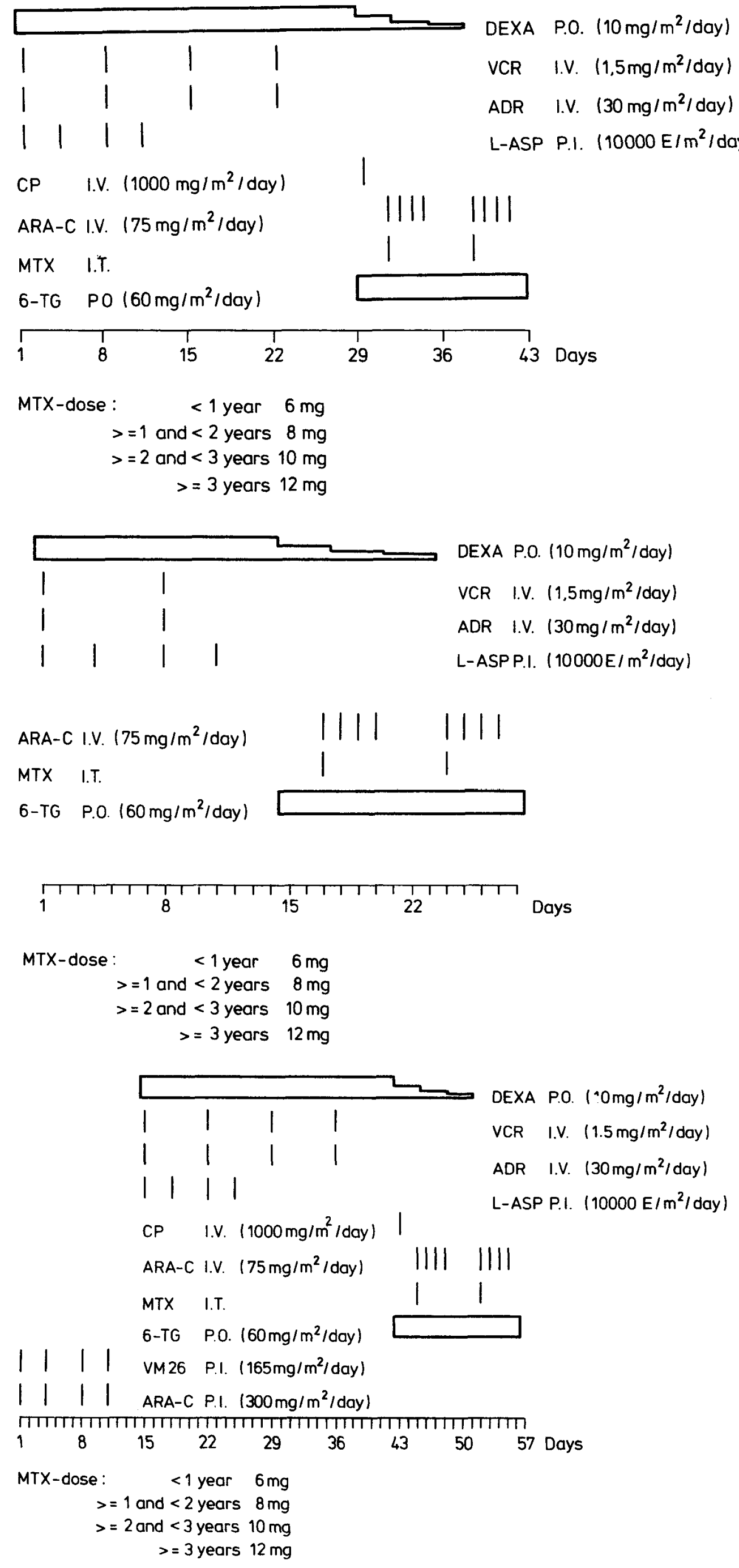

Fig. 3. Outline for the reinduction protocol II (MR patients)

Fig. 4. Outline for the reinduction protocol III (SR patients)

Fig. 5. Outline for the reinduction protocol IV (HR patients) 
sisting of two phases, was identical for each risk group. The reinforced reinduction protocols were risk adjusted: protocol III for SR, protocol II for MR, and protocol IV for HR patients. For prophylactic CNS therapy in the SR group, patients were randomized to receive cranial irradiation and intrathecal methotrexate (MTX) or medium dose methotrexate $\left(500 \mathrm{mg} / \mathrm{m}^{2}\right)$ and intrathecal methotrexate (Fig. 1). For the duration of maintenance therapy, patients were randomized after 78 weeks to receive MTX and 6-MP for another 6 months or protocol III. The induction therapy of the BFM scheme was modified by reducing L-asparaginase in dose and duration. The reinduction with protocol III before stopping therapy was the second modification to the BFM protocol.

\section{Statistical Analysis}

Complete remission (CR) was defined as less than 5\% bone marrow and no evidence of extramedullary leukemia. Kaplan-Meier analysis were performed for survival and continuous $\mathrm{CR}$. Failure is defined as induction failure, initial relapse at any site, death during induction, or death during initial $\mathrm{CR}$.

\section{Results}

Preliminary results are summarized in Table 2. It was found that $93 \%$ of patients attained CR after 4 weeks of therapy. The cumulative proportion in continuous $\mathrm{CR}$ is $0.77 \pm 0.04$ for the total group of 195 patients (Fig. 6). No significant difference was found between the treatment groups SR $(0.83 \pm 0.04)$ and MR $(0.78 \pm 0.07)$ (Fig. 7). Of $14 \mathrm{HR}$ patients, 11 (79\%) attained $C R$. One died in $C R$ and four relapsed (three bone marrow relapses, one CNS relapse). Thus, the proportion in continuous CR was $0.19 \pm 0.16$. Of the total number of children, 12 relapsed. Eight patients had isolated marrow relapse. Isolated CNS relapses occurred in two children. One patient had a simultaneous marrow and CNS relapse and one patient had an isolated relapse in the eye. Patients with

Table 2. Summary of results

\begin{tabular}{|c|c|c|c|c|c|c|c|c|}
\hline \multirow{2}{*}{$\begin{array}{l}\text { Results of therapy } \\
\text { (0-30 months) }\end{array}$} & \multicolumn{2}{|c|}{ Total } & \multicolumn{2}{|l|}{ SR } & \multicolumn{2}{|c|}{ MR } & \multicolumn{2}{|c|}{ HR } \\
\hline & $N$ & $(\%)$ & $N$ & $(\%)$ & $N$ & $(\%)$ & $N$ & $(\%)$ \\
\hline Patients & 195 & 100 & 124 & 100 & 57 & 100 & 14 & 100 \\
\hline Not yet in remission & 13 & & 9 & & 3 & & 1 & \\
\hline Early deaths & 9 & 5 & 5 & 4 & 1 & 2 & 3 & 21 \\
\hline Deaths in initial stage & 5 & 3 & 3 & 3 & 2 & 4 & 0 & \\
\hline Complete remission & 181 & 93 & 116 & 94 & 54 & 95 & 11 & 79 \\
\hline Deaths in remission & 8 & 4 & 5 & 4 & 2 & 4 & 1 & 7 \\
\hline Relapses & 12 & 6 & 4 & 3 & 4 & 7 & 4 & 29 \\
\hline $\mathrm{BM}$ & 8 & 4 & 2 & 2 & 3 & 5 & 3 & 21 \\
\hline CNS & 2 & 1 & 1 & 1 & - & - & 1 & 7 \\
\hline $\mathrm{BM}+\mathrm{CNS}$ & 1 & 1 & - & - & 1 & 2 & - & - \\
\hline Testes & - & - & - & - & - & - & - & - \\
\hline Others (eye) & 1 & 1 & 1 & 1 & - & - & - & - \\
\hline In first remission & 161 & 82 & 107 & 86 & 48 & 84 & 6 & 43 \\
\hline Alive & 168 & 86 & 109 & 88 & 50 & 88 & 9 & 64 \\
\hline $\begin{array}{l}\text { Proportion in continuous } \\
\text { complete remission }\end{array}$ & \multicolumn{2}{|c|}{$0.77 \pm 0.04$} & \multicolumn{2}{|c|}{$0.83 \pm 0.04$} & \multicolumn{2}{|c|}{$0.78 \pm 0.07$} & \multicolumn{2}{|c|}{$0.19 \pm 0.16$} \\
\hline $\begin{array}{l}\text { Median time of remission } \\
\text { (months) }\end{array}$ & \multicolumn{2}{|l|}{12} & \multicolumn{2}{|l|}{12} & \multicolumn{2}{|l|}{12} & \multicolumn{2}{|l|}{12} \\
\hline
\end{tabular}




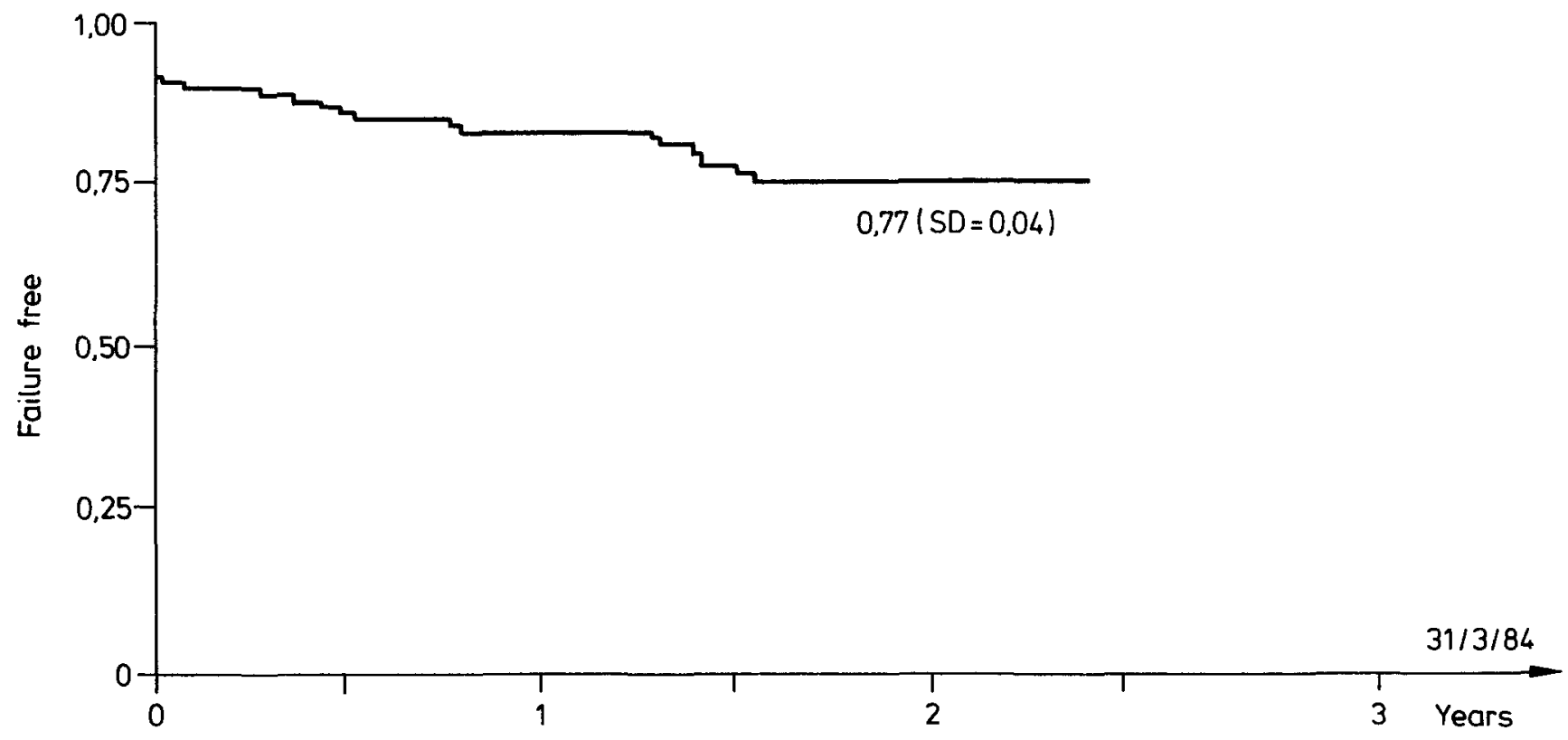

Fig. 6. Probability of continuous complete remission (195 patients, 161 in continous complete remission). Failure $=$ end of remission by relapse or death for any reason

initial WBC above $50 \mathrm{Gpt} / 1$ did worse than those who had WBC below $150 \mathrm{Gpt} / 1$ (Fig. 8). There were no significant differences in failure-free survival in SR and MR patients with WBC greater or less than $125 \mathrm{Gpt} / \mathrm{l}$. Within the groups of SR and MR

Fig. 7. Difference in the duration of continous complete remission (CCR) of the three risk groups. Dotted line standard risk (124 patients, 107 in CCR); full line medium risk (57 patients, 48 in CCR); dashed line high risk (14 patients, 6 in $\mathrm{CCR}$ ) patients, mediastinal mass was not significantly related to outcome. The differences over the total group for the parameters thymic involvement and age are closely related to high WBC in HR patients.

\section{Discussion}

Kaplan-Meier life table analysis of failurefree survival data for 195 patients with ALL of different risk estimates that $77 \% \pm 8 \%$ of patients will be in continuous CR 30 months after diagnosis. Although the median time of remission in our study is just 12 months, these results represent a marked improvement compared with former studies. Our results support the hypothesis of

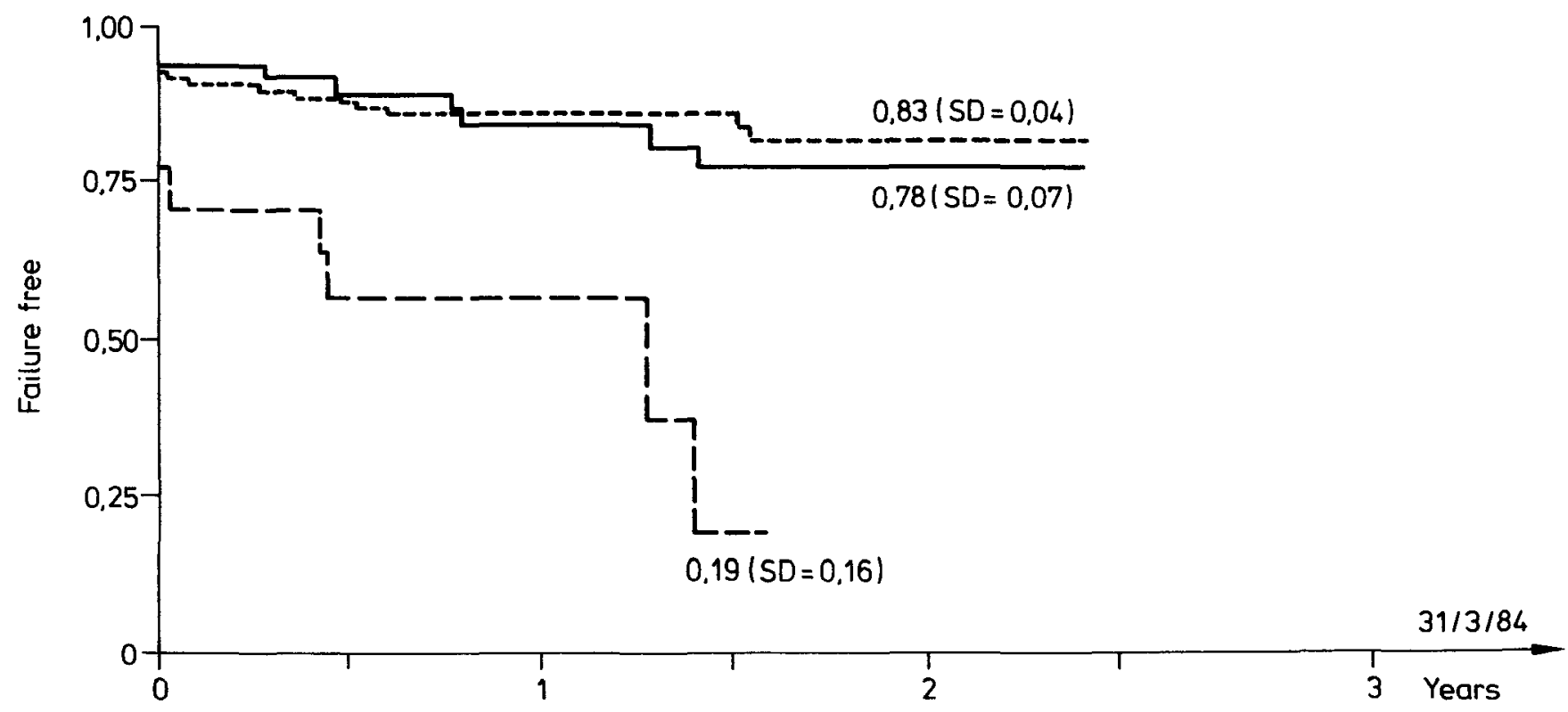




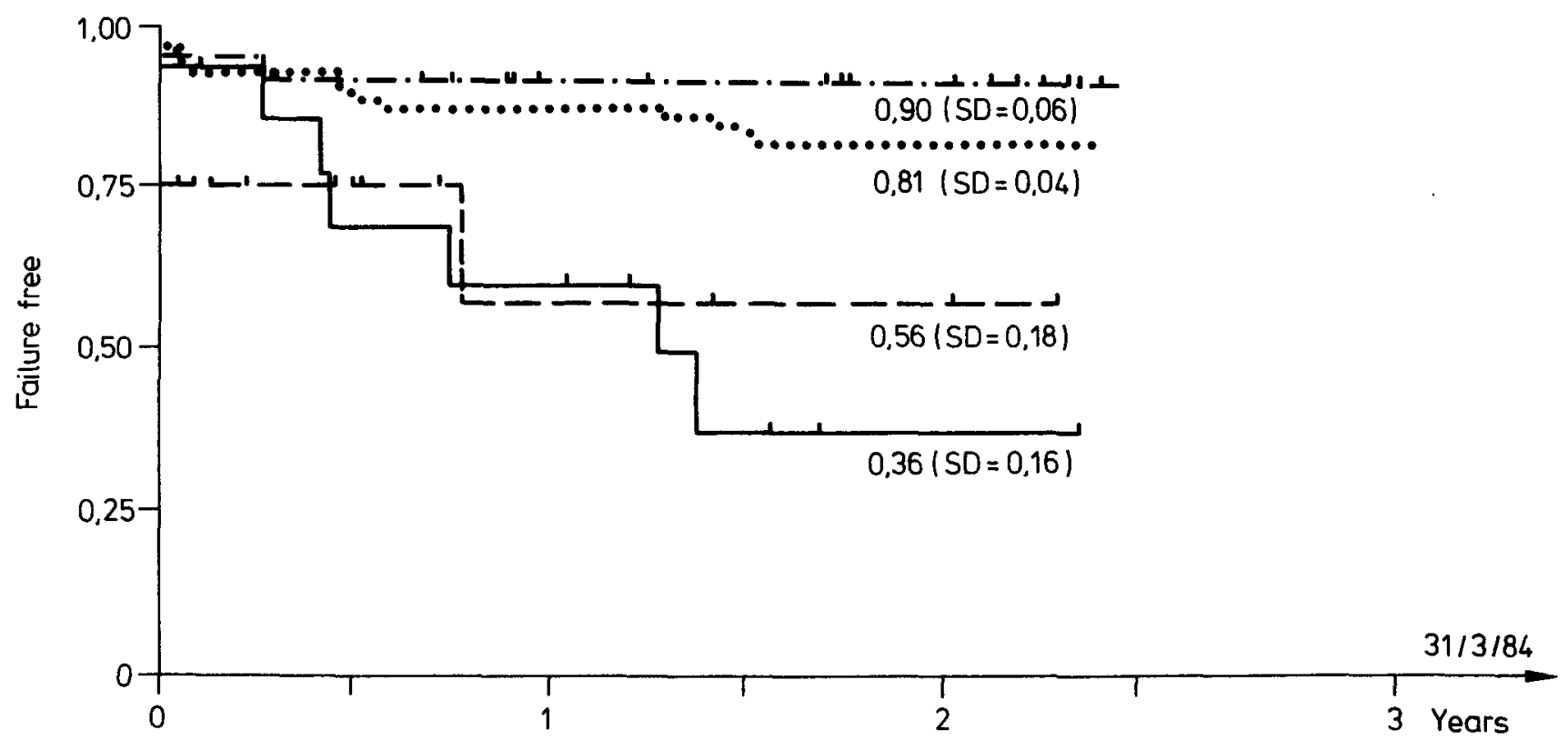

Fig. 8. Probability of continuous complete remission (CCR) in patients with different initial white blood cell counts. Dotted line $<25 \mathrm{Gpt} / 1$ (142 patients, 122 in CCR); dashed-dotted line 25-50 Gpt/1 (22 patients, 18 in CCR); dashed line 50-100 Gpt/1 (16 patients, 11 in CCR); full line $>100 \mathrm{Gpt} / 1$ (15 patients, 8 in CCR)

the BFM group that intensification and prolongation of remission induction produce a higher percentage of disease-free long-term survivors $[2,5]$. Patients in the HR group (risk factor $>1.7$ ) did worse than those in the SR and MR groups. This is in marked contrast to the results reported by the BFM group [5].

\section{References}

1. Zintl F, Hermann J, Katenkamp D, Malke H, Plenert W (1983) Results of $\mathrm{LSA}_{2} \mathrm{~L}_{2}$ therapy in children with high risk acute lymphoblastic leukemia and non-Hodgkin's lymphoma. In:
Neth R, Gallo RC, Greaves MF, Moore MAS, Winkler K (eds) Modern trends in human leukemia, vol V. Springer, Berlin Heidelberg New York Tokyo, pp 62-66

2. Riehm H, Gadner $H$, Henze $G$, Langermann HJ, Odenwald E (1980) The Berlin childhood acute lymphoblastic leukemia therapy study, 1970-1976. Am J Ped Hematol Oncol 2:299-306

3. Riehm H, Henze G, Langermann HJ (1981) Multizentrische Therapiestudie BFM 81 zur Behandlung der akuten lymphoblastischen Leukämie im Kindes- und Jugendalter. Studienprotokoll, 1981

4. Langermann HJ, Henze G, Wulf M, Riehm $H$ (1982) Abschätzung der Tumorzellmasse bei der akuten lymphoblastischen Leukämie im Kindesalter: prognostische Bedeutung und praktische Anwendung. Klin Pädiatr 194:209 $-213$

5. Henze G, Langermann HJ, Fengler $R$ et al. (1982) Therapiestudie BFM 79/81 zur Behandlung der akuten lymphoblastischen Leukämie bei Kindern und Jugendlichen: intensivierte Reinduktionstherapie für Patientengruppen mit unterschiedlichem Rezidivrisiko. Klin Pädiatr 194: 195-203 